\title{
Supplementation of $\boldsymbol{R} \boldsymbol{R} \boldsymbol{R}-\alpha$-Tocopheryl Acetate to Periparturient Dairy Cows in Commercial Herds with High Mastitis Incidence
}

\author{
K. Persson Waller, ${ }^{\star} \dagger^{1}$ C. Hallén Sandgren, $\ddagger$ U. Emanuelson, $\dagger$ and S. K. Jensen§ \\ *Department of Pigs, Poultry and Ruminants, National Veterinary Institute, SE-751 89 Uppsala, Sweden \\ †Department of Clinical Sciences, Swedish University of Agricultural Sciences, Uppsala, Sweden \\ $\ddagger$ Kalmar-Tjust Husdjur, Kalmar, Sweden \\ §Department of Animal Health, Welfare and Nutrition, Research Centre Foulum, Danish Institute of Agricultural Sciences, Tjele, Denmark
}

\begin{abstract}
Dietary vitamin E supplementation of dairy cows around calving has been associated with improved udder health. However, few studies have been performed in Europe and in commercial dairy herds. Therefore, the main aim of the study was to evaluate whether extra daily dietary supplementation of $1,610 \mathrm{mg}$ of $\alpha$ tocopherol, in the form of $R R R$ - $\alpha$-tocopheryl acetate, to dairy cows around calving could improve the udder health in commercial herds with a high incidence of veterinary-treated clinical mastitis. In addition, the effects of supplementation on other cow diseases, fertility, milk production, culling, and stillbirth were also studied. Cows in 21 herds in southeast Sweden were assigned to 1 of 2 groups, 1) daily supplementation with $1,610 \mathrm{mg}$ of $R R R$ - $\alpha$-tocopherol from $4 \mathrm{wk}$ before to 2 wk after calving ( $\mathrm{n}=196)$, or 2$)$ no extra supplementation $(\mathrm{n}=203)$, on top of the normal diet containing average vitamin $\mathrm{E}$ supplementation (on average, 386, 664 , and $957 \mathrm{mg} / \mathrm{d}$ to cows at $1 \mathrm{mo}$ prior to calving, at calving, and at $15 \mathrm{~d}$ after calving, respectively). Multivariable generalized linear mixed models were used for statistical analyses of the effects of supplementation on the cumulative incidence risk of veterinary-treated clinical mastitis and of veterinary-treated diseases other than mastitis within 1 and 2 mo after calving, culling (due to udder health or other reasons) within 2 and $9 \mathrm{mo}$ after calving, the risk of stillbirth or calf death within $24 \mathrm{~h}$ after calving, time from calving to first insemination, number of inseminations per service period, and cow composite natural logarithm of somatic cell count and daily milk production at the first monthly testing after calving. A significant effect of supplementation was observed only for stillbirth or calf death within $24 \mathrm{~h}$ after birth, which was significantly lower
\end{abstract}

Received July 4, 2006.

Accepted February 26, 2007.

${ }^{1}$ Corresponding author: Karin.Persson-Waller@sva.se in the supplemented group. The reasons for this finding require further study.

Key words: vitamin E, dairy cow, udder health, stillborn calf

\section{INTRODUCTION}

Healthy cows are the foundation for sustainable milk production. However, mastitis and other infectious diseases are common problems in dairy herds, resulting in increased costs and decreased production. Most diseases in dairy cows occur at or just after calving, which is a period associated with immune suppression, resulting in an increased susceptibility to infections (reviewed by Mallard et al., 1998; Persson Waller, 2000).

The vitamin E ( $\alpha$-tocopherol) status of dairy cows is one important component of a well-functioning immune system because of its antioxidant effects (Hogan et al., 1993; Politis et al., 1996). Optimal blood $\alpha$-tocopherol concentrations are difficult to maintain around calving because of secretion of the vitamin into the udder during colostrogenesis, decreased DMI at calving, and an increased need for antioxidants during this time (Goff and Stabel, 1990; Weiss et al., 1990b; Meglia et al., 2006). Thus, vitamin $\mathrm{E}$ has been implicated as one factor associated with periparturient immune suppression.

Vitamin $\mathrm{E}$ is a fat-soluble vitamin and is not synthesized in the rumen. The vitamin $\mathrm{E}$ requirement must therefore be provided in the feed. However, the vitamin $\mathrm{E}$ content of the basal diet is highly variable and is not known in most situations. The vitamin $\mathrm{E}$ content is high in fresh grass, but storage and conservation reduce the forage content markedly. Because of these conditions, the NRC (2001) recommends that the total vitamin E requirement should be given via dietary supplements when conserved forages are fed, and that extra supplementation may be useful during periods of immune suppression, such as around calving.

The effects on udder health of dietary supplementation with synthetic vitamin $\mathrm{E}$ around calving have 
yielded varying results. Some studies have reported a reduced incidence of clinical mastitis after supplementation (Smith et al., 1984; Hogan et al., 1993; Weiss et al., 1997), but other studies have found no such effect (Batra et al., 1992; Paschoal et al., 2005). A favorable effect on SCC also has been reported (Batra et al., 1992; Weiss et al., 1997; Baldi et al., 2000). The above-mentioned studies were all controlled studies performed in research herds or in one selected herd. In studies including several commercial herds, Weiss et al. (1990a) found a positive relationship between vitamin $\mathrm{E}$ cow status or dietary content and udder health, but this relationship was not found in other studies (Erskine et al., 1987; Ndiweni et al., 1991; Jukola et al., 1996; LeBlanc et al., 2004). The basal vitamin $\mathrm{E}$ and Se status of the animals in these prior studies was important and may have influenced the effect of vitamin E supplementation (NRC, 2001). Moreover, infection pressure and other nutrient interactions may also have confounded the effects of vitamin E supplementation.

To our knowledge, very few studies on the effects on udder health of dietary supplementation of vitamin $\mathrm{E}$ to transition cows have been performed in Europe (Baldi et al., 2000). The benefit of extra vitamin E must be assumed to vary largely according to differences in the diet, but also according to management systems, milk yield, and infection pressure (Allison and Laven, 2000). In most Swedish dairy farms, the diet is based on grass silage, which has a higher vitamin $\mathrm{E}$ content than, for example, hay or corn silage (Putnam and Comben, 1987; Knudsen et al., 2001). Moreover, in most studies (as well as in most commercial supplements), synthetic vitamin E (all-rac- $\alpha$-tocopheryl acetate) has been used. However, the biological activity of synthetic vitamin $\mathrm{E}$ is considerably lower than that of natural vitamin $\mathrm{E}(R R R$ - $\alpha$-tocopherol; Hidiroglou et al., 1988; Meglia et al., 2006). Thus, it is plausible that natural vitamin $\mathrm{E}$ would have the best effect on udder health, but to our knowledge, this has not been studied in commercial herds.

The aim of the study was therefore to evaluate the effects on udder health of extra daily dietary supplementation of $1,610 \mathrm{mg}(2,400 \mathrm{IU})$ of $\alpha$-tocopherol, in the form of $R R R$ - $\alpha$-tocopheryl acetate, to dairy cows around calving in commercial herds in southeast Sweden with a high incidence of veterinary-treated clinical mastitis (VTCM). The daily dose was based on previous studies (Weiss et al., 1990a,b; Hidiroglou et al., 1997; Weiss et al., 1997; Meglia et al., 2006), as well as on several pilot studies in commercial farms in Denmark and Sweden. The effects of supplementation on other cow diseases, fertility, milk production, culling, and stillbirth were also studied.

\section{MATERIALS AND METHODS}

\section{Herds and Animals}

The study was conducted in 21 dairy herds in southeast Sweden. Inclusion criteria for herds were participation in the official milk recording program, a minimum of 40 milking cows, milk production above the country mean for herds participating in the official milk recording program $(8,794 \mathrm{~kg} / \mathrm{cow}$ and year), the possibility of feeding cows individually (i.e., tie-stall herds), and more than 25 diagnosed cases of VTCM per 100 completed or interrupted lactations before the start of the trial. At the start of the study (October 2003), information about the diet, with emphasis on vitamin supplementation, for cows and heifers 1 mo before calving, at calving, and $15 \mathrm{~d}$ after calving were collected via onfarm interviews performed by one project investigator. Information on the vitamin $\mathrm{E}$ and Se contents of commercial vitamin-mineral feeds and concentrates were collected from the manufacturers.

\section{Experimental Design}

In each herd, cows calving between November 2003 and April 2004 (i.e., during the indoor season) were randomly (odd or even identity number) divided in 2 groups and given daily supplementation of $1,610 \mathrm{mg}$ of $\alpha$-tocopherol (RRR- $\alpha$-tocopheryl acetate, Natur-E granulat $40 \%$, Pharmalett A/S, Kolding, Denmark) on top of the normal diet from 4 wk before expected calving to 2 wk after calving (E), or no extra supplementation (C). The supplement was given once per day (at the morning feeding) by pouring one level measure of granules (using a premeasured scoop provided by the project investigator) on top of the grass silage. None of the animals had access to pasture during the study period. In a subsample of cows and herds, cow composite milk samples were taken by the farmer $4 \mathrm{~d}$ after calving and were frozen $\left(-20^{\circ} \mathrm{C}\right)$ until analyzed for $\alpha$-tocopherol and Se. The numbers of veterinary-treated diseases, fertility records, stillborn calves (including calves dead within $24 \mathrm{~h}$ after birth), and monthly milk production and SCC data were collected from the official milk- and health-recording programs up to 9 mo after calving. It should be noted that in Sweden, only veterinarians are allowed to start an antibiotic treatment, and every treatment should be reported to the national animal disease recording system (Olsson et al., 2001).

\section{Milk Analyses of $\alpha$-Tocopherol and Se}

Milk samples were thawed, heated at $40^{\circ} \mathrm{C}$ for $20 \mathrm{~min}$, and mixed thoroughly prior to analysis. The extraction procedure for tocopherols was as follows. A quantity of 
$1,000 \mathrm{mg}$ of milk was diluted with $0.5 \mathrm{~mL}$ of ascorbic acid solution $(200 \mathrm{~g} / \mathrm{L}), 0.5 \mathrm{~mL}$ of methanol, $2.0 \mathrm{~mL}$ of ethanol, and $0.5 \mathrm{~mL}$ of $\mathrm{KOH}$-water $(1: 1 \mathrm{wt} / \mathrm{vol})$. The final volume of the saponification mixture was adjusted to $5.5 \mathrm{~mL}$ with water. Saponification was carried out at $80^{\circ} \mathrm{C}$ for $20 \mathrm{~min}$. After cooling, tocopherol was extracted twice using $5 \mathrm{~mL}$ of heptane per occasion. The 2 extracts were mixed, and $100 \mu \mathrm{L}$ was injected onto a high-performance liquid chromatograph for tocopherol analysis. All solvents used were of HPLC quality. The HPLC column consisted of a $4.0 \times 125 \mathrm{~mm}$ PerkinElmer HS5-Silica column. Heptane containing 2-propanol (3.0 $\mathrm{mL} / \mathrm{L}$ ) and degassed with helium constituted the mobile phase. The flow rate was $3.0 \mathrm{~mL} / \mathrm{min}$ and the column was held at room temperature. Fluorescence detection was performed with excitation and emission wavelengths of 290 and $327 \mathrm{~nm}$, respectively. Identification and quantification of $\alpha$-tocopherol were obtained by comparison of retention times, as well as peak areas, with external standards (Merck, Darmstadt, Germany), and an extinction coefficient of $\mathrm{A}_{1 \mathrm{~cm}}^{1 \%}=71.0$ at $294 \mathrm{~nm}$ was used for $\alpha$-tocopherol, as previously described by Jensen and Nielsen (1996).

Milk Se was analyzed at the Department of Chemistry, National Veterinary Institute, Uppsala, Sweden, using hydrid generation inductively coupled plasma atomic emission spectrometry (ICP-AES, Jobin Yvon 238 emission-spectrometer, Jobin Yvon SAS, Longjumeau Cedex, France), with setup and conditions according to methods accredited by the SWEDAC (Swedish Board for Accreditation and Conformity Assessment, Borås, Sweden).

\section{Statistics}

Cow milk vitamin $\mathrm{E}$ and Se contents $4 \mathrm{~d}$ after calving in the 2 groups were compared using Student's $t$-test. The same test was used to compare basal supplementation of vitamin $\mathrm{E}$ and Se of heifers or primiparous cows and multiparous cows before, at, and after calving.

The effects of treatment on risk of VTCM and on veterinary-treated diseases other than mastitis within 1 and 2 mo after calving, culling (because of udder health or other reasons) within 2 and 9 mo after calving, and risk of stillbirth or calf death within $24 \mathrm{~h}$ after calving were studied using logistic regression models. The effect of treatment on cow fertility, measured as the number of inseminations per service period, was studied using a Poisson regression model. The effect of treatment on cow fertility, measured as the days from calving to first insemination, was studied using the Cox proportional hazards model, where cows without any insemination were considered censored at the end of the observation period $(9 \mathrm{mo})$ or the day the cow left the herd (culled or sold), whichever came first. Effects of treatment on cow composite $\operatorname{lnSCC}$ and milk production at the first monthly testing after calving were studied using linear regression models. In addition to the effects of treatment, all statistical models included the fixed effects of breed of cow (Swedish Holstein, Swedish Red and White, other), lactation number $(1,2, \geq 3)$, month of calving (November through April), and genetic merit for milk production of the sire of the cow (categorized into thirds). The linear, logistic, and Poisson regression models also included the random effect of herd, whereas the Cox model was stratified by herd. In addition, the models on risks for diseases and culling included the effect of days at risk (DAR), the model on number of inseminations per service period included the effect of days from calving to first insemination and applied lnDAR as an offset variable, and the models on lnSCC and milk production included the effect of DIM at the test. The DAR was the number of days from calving until the end of the observation period $(1,2$, or $9 \mathrm{mo}$ ) or until the cow left the herd (culled or sold), whichever came first.

To investigate the possible effects of herd-status of vitamin $\mathrm{E}$ and Se on the effect of treatment, all multivariable analyses were also performed including such variables and interaction terms between such variables and treatment. Herd status was based on the average vitamin $\mathrm{E}$ and Se contents in cow composite milk samples taken from C-group cows $4 \mathrm{~d}$ after calving. Herds were categorized as either below or above the population median of each variable.

\section{RESULTS}

The mean (range) number of cows, annual milk production per cow, number of diagnosed cases of VTCM per 100 completed or interrupted lactations, and annual bulk milk SCC in the participating herds at the time of selection were 50 (42 to 78 ), $9,607 \mathrm{~kg}$ (8,667 to 12,720 $\mathrm{kg}), 32$ (25 to 51 ), and 218,000 cells $/ \mathrm{mL}(147,000$ to 343,000 cells $/ \mathrm{mL}$ ), respectively. In all herds, grass silage was fed to both heifers and cows. In most herds, pregnant heifers and dry cows were fed grass silage ad libitum 1 mo before calving. At $15 \mathrm{~d}$ after calving, both primiparous and multiparous cows were offered between $5 \mathrm{~kg}$ of DM of grass silage/d and ad libitum amounts. The total supplementation of vitamin $\mathrm{E}$ and Se via mineral feed and concentrates in the basal diet is given in Table 1. The supplementation of vitamin $\mathrm{E}$ and Se increased, on average, 2.5 and 1.8 times from 1 mo before calving to $15 \mathrm{~d}$ after calving, respectively, with numerically (but not significantly) lower amounts for heifers than cows. 
Table 1. Total amount (mg) of supplementation of vitamin E (all-rac- $\alpha$-tocopheryl acetate) and selenium (sodium selenite) given in the basal diet via a commercial vitamin-mineral feed and concentrates to multiparous cows and heifers or primiparous cows around calving in the participating herds $(\mathrm{n}=16 \text { to } 18)^{1}$

\begin{tabular}{|c|c|c|c|c|c|c|}
\hline \multirow[b]{2}{*}{ Item } & \multicolumn{3}{|c|}{ Multiparous cows } & \multicolumn{3}{|c|}{ Heifers or primiparous cows } \\
\hline & $\begin{array}{c}1 \text { mo prior } \\
\text { to calving } \\
(\mathrm{n}=16)\end{array}$ & $\begin{array}{l}\text { At calving } \\
(\mathrm{n}=18)\end{array}$ & $\begin{array}{l}15 \mathrm{~d} \text { after } \\
\text { calving } \\
(\mathrm{n}=16)\end{array}$ & $\begin{array}{c}1 \text { mo prior } \\
\text { to calving } \\
(\mathrm{n}=17)\end{array}$ & $\begin{array}{l}\text { At calving } \\
(\mathrm{n}=17)\end{array}$ & $\begin{array}{c}15 \mathrm{~d} \text { after } \\
\text { calving } \\
(\mathrm{n}=16)\end{array}$ \\
\hline \multicolumn{7}{|c|}{ Vitamin E } \\
\hline Mean & 386 & 664 & 957 & 322 & 569 & 882 \\
\hline SD & 289 & 577 & 381 & 207 & 607 & 355 \\
\hline Median & 367 & 538 & 900 & 360 & 435 & 850 \\
\hline Range & $0-1,170$ & $150-2,820$ & $570-2,050$ & 0-690 & $150-2,820$ & $450-1,950$ \\
\hline \multicolumn{7}{|l|}{ Selenium } \\
\hline Mean & 4.5 & 6.3 & 8.5 & 4.2 & 5.4 & 7.4 \\
\hline SD & 2.7 & 2.4 & 2.6 & 2.6 & 2.2 & 2.4 \\
\hline Median & 4.4 & 5.9 & 9.0 & 4.3 & 5.3 & 7.3 \\
\hline Range & $0-8.0$ & $3.2-10.8$ & $4.4-12.8$ & $1-8.0$ & $2.4-9.0$ & $3.6-12.2$ \\
\hline
\end{tabular}

${ }^{1}$ Data were not available or were incomplete from some herds. The values for multiparous cows and heifers or primiparous cows at each time point were not significantly different (Student's test, $P>0.05$ ).

In total, 196 E-group cows and 203 C-group cows were included in the study. Cow composite milk samples taken $4 \mathrm{~d}$ after calving were available from 205 cows in 14 herds (minimum of 3 cows per group in each herd). The $\alpha$-tocopherol concentration was $36 \%$ higher $(P<0.001)$ in E-group cows than in C-group cows (Table 2 ). An increase was observed in all herds, but varied from 14 to 57\% (data not shown). Samples for analysis of Se were available from only 129 animals in 12 herds and did not differ significantly between groups (Table 2).

Overall means and confidence intervals of the health, culling, fertility, and production parameters tested for associations with vitamin $\mathrm{E}$ supplementation are given in Table 3. The multivariable analyses did not detect any significant differences between C-group and Egroup cows in the risk of cow diseases within 1 and 2 mo after calving, or the risk of culling within 2 and 9 mo after calving. Likewise, milk production and SCC at the first monthly testing after calving and fertility parameters did not differ significantly between groups. In contrast, a significantly $(P=0.035)$ lower risk of stillborn calves was found in E-group than in C-group cows (odds ratio $=0.38 ; 95 \%$ confidence interval $=0.15$ 0.95). The herd average milk $\alpha$-tocopherol and Se con- tents of C-group cows at $4 \mathrm{~d}$ after calving did not have a significant effect on the results.

\section{DISCUSSION}

The prevalence of clinical mastitis did not improve after daily dietary supplementation with $1,610 \mathrm{mg}$ of $R R R$ - $\alpha$-tocopherol around calving in the herds included in the study, despite using a relatively large dose of the natural form of vitamin $\mathrm{E}$. This was in agreement with some studies (Batra et al., 1992; Paschoal et al., 2005) in which cows were supplemented with $920 \mathrm{mg}$ of allrac- $\alpha$-tocopherol/d before calving, but was in contrast to other studies (Smith et al., 1984; Hogan et al., 1993; Weiss et al., 1997) in which cows were supplemented with between 700 and 3,700 mg of all-rac- $\alpha$-tocopherol/ $\mathrm{d}$ before calving. Likewise, SCC did not differ between groups at the first monthly sampling after calving in the present study, which was in contrast to findings by Baldi et al. (2000) when cows were supplemented with $920 \mathrm{mg}$ of all-rac- $\alpha$-tocopherol per day around calving. The present study was performed in herds with a relatively high incidence of clinical mastitis, because such herds were considered most likely to benefit from extra supplementation of vitamin $\mathrm{E}$.

Table 2. Mean (SD) concentration of $\alpha$-tocopherol $(\mathrm{mg} / \mathrm{L})$ and selenium $(\mu \mathrm{g} / \mathrm{L})$ in composite milk samples taken $4 \mathrm{~d}$ after calving from control cows (C) and cows supplemented with extra vitamin $\mathrm{E}$ around calving $(\mathrm{E})^{1}$

\begin{tabular}{lccccc}
\hline & & $\mathrm{n}$ & $\mathrm{n}$ & \\
Analysis & $\mathrm{C}$ & $(\mathrm{C}$ cows $)$ & $\mathrm{E}$ & $(\mathrm{E}$ cows $)$ & $P$-value \\
\hline$\alpha$-Tocopherol & $2.0(1.7)$ & 97 & $3.2(2.4)$ & 108 & $<0.001$ \\
Selenium & $16.7(4.0)$ & 58 & $17.1(5.0)$ & 71 & 0.57 \\
\hline
\end{tabular}

${ }^{1}$ Samples were collected from 14 ( $\alpha$-tocopherol) and 12 (selenium) herds, respectively.

${ }^{2}$ Based on Student's $t$-test. 
Table 3. Overall means and 95\% confidence intervals (CI) for cumulative risks of veterinary-treated clinical mastitis within 1 (VTCM1) and 2 (VTCM2) mo after calving, cumulative risks of other veterinary-treated diseases within 1 (VTOD1) and 2 (VTOD2) mo after calving, culling due to mastitis within 2 (MCULL2) and 9 (MCULL9) mo after calving, any culling within 2 (CULL2) and 9 (CULL9) mo after calving, risk of stillborn calves (SB), days from calving to first insemination (CFI), number of inseminations per service period (NINS), and cow composite $\operatorname{lnSCC}$ and daily milk production (kg/d) at the first monthly testing after calving for control cows $(n=203)$ and cows supplemented with extra vitamin $\mathrm{E}$ around calving $(\mathrm{n}=196)$

\begin{tabular}{|c|c|c|c|c|c|c|}
\hline \multirow[b]{2}{*}{ Variable } & \multicolumn{3}{|c|}{ Control cows } & \multicolumn{3}{|c|}{ Vitamin E-supplemented cows } \\
\hline & Mean & Lower CI & Upper CI & Mean & Lower CI & Upper CI \\
\hline VTCM1 $^{1}$ & 0.08 & 0.05 & 0.13 & 0.09 & 0.05 & 0.14 \\
\hline VTCM $2^{1}$ & 0.11 & 0.07 & 0.16 & 0.11 & 0.07 & 0.16 \\
\hline VTOD $^{1}$ & 0.09 & 0.05 & 0.14 & 0.08 & 0.04 & 0.12 \\
\hline VTOD2 ${ }^{1}$ & 0.10 & 0.07 & 0.15 & 0.09 & 0.05 & 0.14 \\
\hline MCULL2 $^{1}$ & 0.01 & 0.00 & 0.04 & 0.01 & 0.00 & 0.03 \\
\hline MCULL9 $^{1}$ & 0.08 & 0.05 & 0.13 & 0.08 & 0.05 & 0.13 \\
\hline CULL2 $^{1}$ & 0.03 & 0.01 & 0.06 & 0.06 & 0.03 & 0.10 \\
\hline CULL9 $^{1}$ & 0.23 & 0.17 & 0.29 & 0.24 & 0.19 & 0.31 \\
\hline $\mathrm{SB}^{1}$ & 0.06 & 0.03 & 0.11 & 0.03 & 0.01 & 0.06 \\
\hline CFI & 93.1 & 87.0 & 99.1 & 85.1 & 80.2 & 90.1 \\
\hline NINS $^{2}$ & 2.06 & 1.84 & 2.30 & 2.29 & 2.05 & 2.55 \\
\hline LnSCC & 1.96 & 1.87 & 2.06 & 1.89 & 1.81 & 1.98 \\
\hline Milk production & 35.0 & 33.7 & 36.2 & 35.6 & 34.2 & 37.0 \\
\hline
\end{tabular}

In the present study, all herds used grass silage as the main roughage both before and after calving, and most herds also gave some basal supplementation of vitamin E, probably resulting in a higher basal content in the diet than in previous studies (Smith et al., 1984; Weiss et al., 1997). The amounts fed via supplements in the present study were, on average, higher than Swedish recommendations at the time of the study (14 $\mathrm{mg}$ of all-rac- $\alpha$-tocopherol/kg of $\mathrm{DM}$ ), but lower than the NRC (2001) recommendations of $73 \mathrm{mg}$ of all-rac$\alpha$-tocopherol/ $/ \mathrm{kg}$ of DM in late gestation and $18 \mathrm{mg} / \mathrm{kg}$ of DM for lactating cows, which are similar to current Swedish recommendations. It is possible that the basal diet, especially the grass silage, gave sufficient vitamin E status, making extra supplementation of limited additional value. The high content of $\alpha$-tocopherol in milk samples from C-group cows supported this hypothesis. In previous studies, the majority of roughage in the diet consisted of haylage before calving (Smith et al., 1984), or grass silage before calving and corn silage after calving (Weiss et al., 1997).

The Se status of the cows may also affect the results (Weiss et al., 1997; NRC, 2001), but in the present study, neither vitamin E nor Se milk herd status influenced the results. It should be noted that herd-level variables, as were used here, do not necessarily describe cow-level variation. The actual cow-level variation could not be described in this study, because it was not possible to sample all cows. It also may be argued that evaluation of vitamin $\mathrm{E}$ and Se status using milk levels is suboptimal, but it was the best method available at the time. A clear relationship between plasma and milk concentrations has been reported for both $\alpha$-tocopherol (Jensen et al., 1999) and Se (Lean et al., 1990; Wichtel et al., 2004). In the above-mentioned studies on udder health, milk vitamin $\mathrm{E}$ and Se contents were either not measured or were not measured at the same time point after calving, making comparisons between studies difficult. The estimated mean supplementation of Se was at or above the NRC (2001) recommendation of $0.3 \mathrm{mg} /$ $\mathrm{kg}$ of dietary DM in the present study, but the variation between herds was considerable. Here, it must be noted that, according to Swedish recommendations, the maximum content of Se in the total diet should not exceed $0.5 \mathrm{mg}$ of Se/kg of dietary DM. Feeding higher amounts than the NRC recommendation was not reflected in higher Se contents in the milk. In comparison, Weiss et al. (1997) used Se at $0.1 \mathrm{mg} / \mathrm{kg}$ of DM, whereas Smith et al. (1984) injected $\mathrm{Se}(0.1 \mathrm{mg} / \mathrm{kg}$ of BW) before calving and used a dietary supplement $(0.3 \mathrm{mg} / \mathrm{kg}$ of DM) during lactation.

Variation in udder pathogens also may have affected the results. According to Allison and Laven (2000), positive effects of vitamin $\mathrm{E}$ on mastitis have been observed mainly in connection with environmental udder pathogens. In Sweden, contagious pathogens are the most common finding in clinical mastitis (Bengtsson et al., 2005), but the bacteriological profile of the mastitis cases in this study was not known.

The only significant difference found between treatments in the present study was a lower risk of stillborn calves or calf death within $24 \mathrm{~h}$ after birth in the vita- 
min E group. To our knowledge, this has not been reported before in cattle, but a decrease in the number of stillborn piglets was observed after vitamin E supplementation of sows (Mahan, 1994). The reasons for the finding are not clear but may be due to vitamin effects on maternal immune status, placental function, prostaglandin synthesis, or transfer of nutrients to the fetus (Panganamala and Cornwell, 1982; Allison and Laven, 2000; Capper et al., 2005). A reduction in the prevalence of retained fetal membranes in cows has been reported after supplementation of vitamin E, especially if the original vitamin level was marginal (Allison and Laven, 2000). This is probably due to stimulatory effects of vitamin $\mathrm{E}$ on neutrophil activity, because decreased neutrophil function is associated with retained fetal membranes (Kimura et al., 2002). In the present study, only 4 cases of retained fetal membranes were reported ( 1 and 3 in C- and E-group cows, respectively) making it unsuitable to include this variable in the statistical analyses.

Improved immune status is likely to have positive effects on the general health of the cow during pregnancy by reducing the incidence of infectious diseases that consume antioxidants as well as other nutrients. Thus, more nutrients may be available for transport to the fetus, with positive effects on its growth and wellbeing. Transfer of vitamin $\mathrm{E}$ to the fetus via the placenta has been considered to be low because newborn calves have no or very low levels of vitamin E (Van Saun et al., 1989). However, Capper et al. (2005) recently found that supplementation of vitamin $\mathrm{E}$ to ewes during late pregnancy gave significantly higher levels of vitamin $\mathrm{E}$ in fetal tissues despite very low levels in fetal plasma.

A low maternal intake of vitamin $\mathrm{E}$, Se, or both during late pregnancy can cause nutritional muscular dystrophy in calves, which may result in stillborn calves or calves dying within a few days after birth (e.g., Allison and Laven, 2000). Because autopsies were not performed in the present study, it is not known whether the stillborn calves suffered from muscular dystrophy. The relative importance of vitamin $\mathrm{E}$ and Se in prevention of the disease is not clear. However, Se supplementation and Se concentrations in the milk did not differ between groups in this study. Moreover, the results did not indicate a state of Se deficiency in any cow, even though the levels in milk were considered marginal [i.e., 11 to $18 \mu \mathrm{g} / \mathrm{L}$ according to Puls (1994) and 9.6 to $21.8 \mu \mathrm{g} / \mathrm{L}$ according to Wichtel et al. (2004)] in the majority of the cases, which may have negative effects on health and production.

Our result in stillborn calves is interesting, but the possibility of finding associations based on chance alone increases when many risk factors are studied in a single data set. This, together with the low total number of stillborn calves (12 and 4 in C- and E-group cows, respectively), means that the results must be treated with some care and should be confirmed in other studies.

Unfortunately, it was not possible to design the study so that the producers, who also identified the disease outcomes, were blinded to the treatment. Thus, it cannot be excluded that the results were biased by the subconscious or conscious actions of the producers, or both. However, the results do not indicate such an effect because no differences were found in disease outcomes.

\section{CONCLUSIONS}

The results did not indicate that extra daily supplementation of $1,610 \mathrm{mg}$ of $\alpha$-tocopherol, in the form of $R R R$ - $\alpha$-tocopheryl acetate, around calving had any significant effects on udder health, or on other cow health problems or fertility in the herds participating in the study. The risk for stillbirth or calf death within 24 $\mathrm{h}$ after birth was, however, significantly lower in the supplemented group. The reasons for this finding require further study.

\section{ACKNOWLEDGMENTS}

The authors wish to thank the Swedish Farmers Foundation for Agricultural Research for financial support, Christina Karlsson and Karin Thunberg for excellent technical support, and Pharmalett A/S, Denmark, for providing the vitamin E granulate.

\section{REFERENCES}

Allison, R. D., and R. A. Laven. 2000. Effect of vitamin E supplementation on the health and fertility of dairy cows: A review. Vet. Rec. 147:703-708.

Baldi, A., G. Savoini, L. Pinotti, E. Monfardini, F. Cheli, and V. Dell'Orto. 2000. Effects of vitamin $\mathrm{E}$ and different energy sources on vitamin E status, milk quality and reproduction in transition cows. J. Vet. Med. A 47:599-608.

Batra, T. R., M. Hidiroglou, and M. W. Smith. 1992. Effect of vitamin $\mathrm{E}$ on incidence of mastitis in dairy cattle. Can. J. Anim. Sci. 72:287-297.

Bengtsson, B., H. Unnerstad, T. Ekman, K. Persson Waller, A. Lindberg, K. Artursson, J. Jovanovic, and M. Nilsson Öst. 2005. Prevalence and antimicrobial susceptibility of bacteria causing acute clinical mastitis in dairy cows in Sweden 2002-03. Page 888 in Mastitis in Dairy Production: Current Knowledge and Future Solutions. Proc. 4th Int. Mastitis Conf., Maastricht, the Netherlands. H. Hogeveen, ed. Wageningen Academic Publishers, Wageningen, the Netherlands.

Capper, J. L., R. G. Wilkinson, E. Kasapidou, S. A. Pattinson, A. M. Mackenzie, and L. A. Sinclair. 2005. The effect of dietary vitamin $\mathrm{E}$ and fatty acid supplementation of pregnant and lactating ewes on placental and mammary transfer of vitamin $\mathrm{E}$ to the lamb. Br. J. Nutr. 93:549-557.

Erskine, R. J., R. J. Eberhardt, L. J. Hutchinson, and R. W. Scholz. 1987. Blood selenium concentrations and glutathione peroxidase activities in dairy herds with high and low somatic cell counts. J. Am. Vet. Med. Assoc. 190:1417-1421. 
Goff, J. P., and J. R. Stabel. 1990. Decreased plasma retinol, $\alpha$ tocopherol and zinc concentration during the periparturient period: Effect of milk fever. J. Dairy Sci. 73:3195-3199.

Hidiroglou, M., T. R. Batra, and X. Zhao. 1997. Bioavailability of vitamin $\mathrm{E}$ compounds and the effect of supplementation on release of superoxide and hydrogen peroxide by bovine neutrophils. J. Dairy Sci. 80:187-193.

Hidiroglou, N., L. F. Laflamme, and L. R. McDowell. 1988. Blood plasma and tissue concentrations of vitamin $\mathrm{E}$ in beef cattle as influenced by supplementation of various tocopherol compounds. J. Anim. Sci. 66:3227-3234.

Hogan, J. S., W. P. Weiss, and K. L. Smith. 1993. Role of vitamin $\mathrm{E}$ and selenium in host defense against mastitis. J. Dairy Sci. 76:2795-2803.

Jensen, S. K., A. K. Bjørnbak Johannsen, and J. E. Hermansen. 1999. Quantitative secretion and maximal secretion capacity of retinol, $\beta$-carotene, and $\alpha$-tocopherol into cows' milk. J. Dairy Res. 66:511-522.

Jensen, S. K., and K. N. Nielsen. 1996. Tocopherols, retinol, $\beta$-carotene and fatty acids in fat globule membrane and fat globule core in cows' milk. J. Dairy Res. 63:565-574.

Jukola, E., J. Hakkarainen, H. Saloniemi, and S. Sankari. 1996. Blood selenium, vitamin $\mathrm{E}$, vitamin $\mathrm{A}$, and $\beta$-carotene among dairy cows with or without mastitis. J. Dairy Sci. 67:1832-1840.

Kimura, K., J. P. Goff, M. E. Kehrli Jr., and T. A. Reinhardt. 2002. Decreased neutrophil function as a cause of retained placenta in dairy cattle. J. Dairy Sci. 85:544-550.

Knudsen, B. S., J. R. Kermansen, S. K. Jensen, T. Kristensen, and M. O. Nielsen. 2001. E-vitamin till mælkekoer-Forekomst og function samt vitaminstatus og sammenhæng till hyppigste produktionssygdomme i økologiske besætninger [in Danish]. DJF Report Husdyrbrug No. 27. Danish Institute of Agricultural Research, Tjele, Denmark.

Lean, I. J., H. F. Troutt, H. Boermans, G. Moller, G. Webster, and M. Tracy. 1990. An investigation of bulk tank milk selenium levels in the San Joaquin Valley of California. Cornell Vet. 80:41-51.

LeBlanc, S. J., T. H. Herdt, W. M. Seymour, T. F. Duffield, and K. E. Leslie. 2004. Peripartum serum vitamin E, retinol, and $\beta$ carotene in dairy cattle and their associations with disease. J. Dairy Sci. 87:609-619.

Mahan, D. C. 1994. Effects of dietary vitamin E on sow reproductive performance over a five-parity period. J. Anim. Sci. 72:2870-2879.

Mallard, B. A., J. C. Dekkers, M. J. Ireland, K. E. Leslie, S. Sharif, C. L. Van Kampen, L. Wagter, and B. N. Wilkie. 1998. Alteration in immune responsiveness during the peripartum period and its ramification on dairy cows and calf health. J. Dairy Sci. 81:589-595.

Meglia, G. E., S. K. Jensen, C. Lauridsen, and K. Persson Waller. 2006. $\alpha$-Tocopherol concentration and stereoisomer composition in plasma and milk from dairy cows fed natural or synthetic vitamin E around calving. J. Dairy Res. 73:227-234.

Ndiweni, N., T. R. Field, M. R. Williams, J. M. Booth, and J. M. Finch. 1991. Studies on the incidence of clinical mastitis and blood levels of vitamin $\mathrm{E}$ and selenium in dairy herds in England. Vet. Rec. 129:86-88.

NRC. 2001. Nutrient Requirements of Dairy Cattle. 7th rev. ed. National Academy Press, Washington, DC.

Olsson, S. O., P. Baekbo, S. O. Hansson, H. Rautala, and O. Østeras. 2001. Disease recording systems and herd health schemes for production diseases. Acta Vet. Scand. 94(Suppl.):51-60.

Panganamala, R. V., and D. G. Cornwell. 1982. The effects of vitamin $\mathrm{E}$ on arachidonic acid metabolism. Ann. N. Y. Acad. Sci. 393:376-391.

Paschoal, J. J., M. A. Zanetti, and J. A. Cunha. 2005. Clinical mastitis in dairy cows supplemented with selenium and vitamin E. Pesq. Agropec. Bras. 40:1043-1046.

Persson Waller, K. 2000. Mammary gland immunology around parturition. Influence of stress, nutrition and genetics. Adv. Exp. Med. Biol. 480:3488-3497.

Politis, I., N. Hidiroglou, J. H. White, J. A. Gilmore, S. N. Williams, H. Scherf, and M. Frigg. 1996. Effects of vitamin E on mammary and blood leukocyte function, with emphasis on chemotaxis, in periparturient dairy cows. Am. J. Vet. Res. 4:468-471.

Puls, R. 1994. Mineral levels in Animal Health: Diagnostic Data. Sherpa International, Clearbrook, Canada.

Putnam, M. E., and N. Comben. 1987. Vitamin E. Vet. Rec. 121:541-545.

Smith, K. L., J. H. Harrison, D. D. Hancock, D. A. Todhunter, and H. R. Conrad. 1984. Effect of vitamin E and selenium supplementation on incidence of clinical mastitis and duration of clinical symptoms. J. Dairy Sci. 67:1293-1300.

Van Saun, R. J., T. H. Herdt, and H. D. Stowe. 1989. Maternal and fetal vitamin E concentrations and selenium-vitamin E interrelationships in dairy cattle. J. Nutr. 119:1156-1164.

Weiss, W. P., J. S. Hogan, K. L. Smith, and K. H. Hoblet. 1990a Relationships among selenium, vitamin $\mathrm{E}$, and mammary gland health in commercial dairy herds. J. Dairy Sci. 73:381-390.

Weiss, W. P., J. S. Hogan, D. A. Todhunter, and K. L. Smith. 1997. Effect of vitamin E supplementation in diets with a low concentration of selenium on mammary gland health of dairy cows. J. Dairy Sci. 80:1728-1737.

Weiss, W. P., D. A. Todhunter, J. S. Hogan, and K. L. Smith. 1990b. Effect of duration of supplementation of selenium and vitamin $\mathrm{E}$ on periparturient dairy cows. J. Dairy Sci. 73:3187-3194.

Wichtel, J. J., G. P. Keefe, J. A. Van Leeuwen, E. Spangler, M. A. McNiven, and E. H. Ogilvie. 2004. The selenium status of dairy herds in Prince Edward Island. Can. Vet. J. 45:124-132. 